\title{
Evaluation of chronic toxicities from sediments before and after ecological project in Meiliang Bay, Lake Taihu, using cell bioassays
}

\author{
Min Qiao, Sheng-Biao Huang, Zijian Wang* \\ State Key Laboratory of Environmental Aquatic Chemistry, Research Center for Eco-Environmental Sciences, \\ Chinese Academy of Sciences, Beijing 100085, China
}

\section{A R T I C L E I N F O}

\section{Article history:}

Received 5 March 2007

Received in revised form

5 September 2008

Accepted 7 November 2008

Keywords:

Bioassay

Sediment

Remediation

Meiliang Bay

Lake Taihu

\begin{abstract}
A B S T R A C T
An ecological project for water purification was conducted in Meiliang Bay, Lake Taihu, which supplies one-third of the drinking water for Wuxi City, China. Sediment dredging was employed. The floating-leaf and floating macrophytes were planted, combined with wave-attenuating, algal bloom blocking to improve the water quality. At the same time, large amounts of fish net were placed in the experimental zone, to which massive periphytes adhere. To evaluate the effectiveness of remediation, many studies were based on chemical analysis or acute toxicity test. In this study, chronic toxicities before and after the ecological project in Meiliang Bay, Lake Taihu, China, were evaluated based on a battery of in vitro bioassays, including EROD bioassay, recombined yeast assay, as well as umu test for detection of Ah-receptor (AhR) agonists, estrogenic chemicals and genotoxic chemicals, respectively. Before remediation, AhR effect, estrogenic effect and indirect genotoxicity were all detected in sediments of Meiliang Bay, Taihu Lake. After amelioration, levels of AhR agonists decreased by $42.3-80.7 \%$, estrogenic chemicals decreased by $71.6-93.9 \%$ and indirect genotoxic chemicals decreased by $23.2-75.0 \%$. Results showed that the ecological project effectively removed the chronic toxicants from the sediments.
\end{abstract}

(c) 2008 Elsevier B.V. All rights reserved.

\section{Introduction}

Over the past years, a number of sediment remediation techniques have been developed to clean up contaminated sites (Carone et al., 2006; Jiang and Shen, 2006), and the studies regarding the effects from remediation have also been reported (Schulz et al., 2001). However, most of the evaluations were based on chemical analysis and focused on a limited number of hazardous compounds (Anderson et al., 2000). Bioassays were also implemented due to the complexity of aquatic systems but were mainly used to measure acute sediment toxicity (Murphy, 2000; Simon et al., 2004). Nowa- days, a variety of persistent organic pollutants (POPs), such as polychlorinated dibenzo-p-dioxins (PCDDs), polychlorinated dibenzofurans (PCDFs), polychlorinated biphenyls (PCBs), and polycyclic aromatic hydrocarbons (PAHs), are of great concern due to their worldwide distribution, high persistency, and hydrophobic nature (Kubota et al., 2004). These persistent toxic substances have a strong affinity for sediments, a high potential for accumulating in biological tissues and potential for causing deterioration of the aquatic ecosystem through long-term exposure and chronic toxicity (Khim et al., 1999; Giesy et al., 2002). For these types of chemicals, toxicity end-points such as survival and mortality are not sufficient to evaluate the removal effectiveness in eco-

\footnotetext{
* Corresponding author: Tel.: +86 10 62849140; fax: +861062849140.

E-mail address: wangzj@rcees.ac.cn (Z. Wang). 


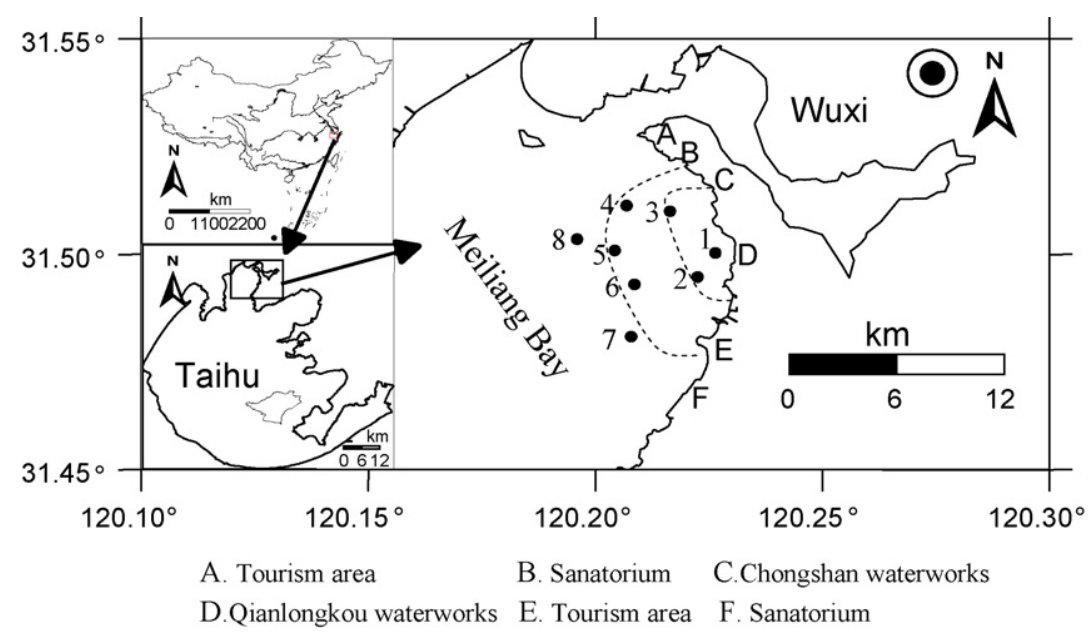

Fig. 1 - Map of study area and sampling sites.

logical projects in aquatic systems. Although instrumental analyses are essential for identification and quantification, instrumental results are not well suited to predict the toxicity of unknown chemicals in the system and the complex interactions of synergism, antagonism, and additivity of known chemicals on biota (Villeneuve et al., 2000; Denison et al., 2004), and chemicals that are biologically active at concentrations less than analytical detection limits may be missed by instrumental analyses. In vitro bioassays can integrate the overall potency of complex samples, and both additive and nonadditive interactions between compounds can be accounted for (Giesy et al., 2002). Thus, in the last decades, many bioassays were used to detect the toxic organic compounds present in complex environmental samples (Khim et al., 1999; Masunaga et al., 2001; Ma et al., 2005) based on their relatively low cost, quick efficiency and high sensitivity, and they are being increasingly used as screening tools in risk assessments.

Among the various in vitro bioassays, the H4IIE rat hepatoma ethoxyresorufin-O-deethylase (EROD) activity assay, recombinant yeast assay and umu test were the most widely used assays to detect aryl hydrocarbon receptor (AhR) effect, estrogen-like activities and genotoxicity, respectively. Dioxin and dioxin-like compounds bind to the AhR transcription factor and induce cytochrome P450 1A (CYP1A) response. The capacity of the extracts to induce CYP1A was determined by measurement of an associated enzyme activity, namely EROD (Stegeman et al., 2001; Miller et al., 2003). In the recombinant yeast screen, the main yeast chromosome contains cDNA of the human $\alpha$-estrogen receptor (hER- $\alpha$ ). When estrogen, or a xenoestrogen, binds to the estrogen receptor, transcription of the lac- $Z$ reporter gene ensues. The lac- $Z$ reporter gene codes for the enzyme $\beta$-galactosidase (Legler et al., 2002; Hamblen et al., 2003). In order to detect potential mutagens and evaluate their ability to cause DNA damage, the umu-test system has been introduced. It is based on the ability of carcinogens and mutagens to induce expression of an umuC gene in Salmonella typhimurium TA1535/pSK1002, in which a plasmid pSK1002 carrying a fused gene umuC-lacZ (Oda et al., 1985; Motohashi and Saito, 2002).
The study area is in Meiliang Bay, located in the northern part of Lake Taihu, the third largest freshwater lake in China. The bay is important for the local water supply and for biological habitats. However, with rapid economic development and population rise, the water quality in Lake Taihu has deteriorated and the water contamination has threatened the water supply and wild animals. To improve the water quality, during the last several years, ecological project was implemented in Meiliang Bay, Lake Taihu. Sediment was dredged. The floatingleaf and floating macrophytes were selected to be planted. Because there prevails southeast or southwest wind, onshore wind flow with long fetch results in high waves, sediment resuspension and algal bloom piled up in experimental area. The submerged macrophytes could not be restored in this kind of situation. Wave-attenuating, algal bloom blocking was also used to improve the water quality. At same time, large amount of fish net were placed in the experimental zone with which massive periphytes adhere to (Qin et al., 2007). The solid suspension (SS) concentration decreased and the sedimentation rate increased after the construction of wave attenuation.

Most of the studies in this field were focused on eutrophication by monitoring many inorganic chemicals and environmental parameters (Zuo et al., 2003). Reports using a batch of bioassays to assess the genotoxicity potentials of pollutants were only carried out on surface water (Wu et al., 2004). In fact, organic pollutants may associate with particulate and dissolved organic matter and deposit onto sediments. So, the objective of this study was to evaluate the sediment chronic toxicities after the remediation project and provide the basis for screening and thoroughly assessing the ecological risk in Meiliang Bay, Lake Taihu.

\section{Methods and materials}

\subsection{Sampling area}

Surface sediment samples were collected from this area in July 2003 and 2005, respectively, using a stainless steel grab sampler with the aid of a global positioning system (GPS). Sampling locations are shown in Fig. 1. Samples were scooped into alu- 
minum jars, which were pre-washed with dichloromethane (DCM) and stored at $-20^{\circ} \mathrm{C}$ after transported to the laboratory until further analyses.

\subsection{Sample preparation}

After being freeze-dried and meshed, the sediment samples were extracted with $200 \mathrm{~mL}$ DCM/acetone $(1: 1, \mathrm{v} / \mathrm{v})$ in a Soxhlet apparatus. Activated copper was added for desulfurization. The extracts were pre-concentrated to $2 \mathrm{~mL}$ by a rotary evaporator (Büchi R-200, Switzerland) and solvent exchanged to hexane (Qiao et al., 2006). The concentrated extract was evaporated to near dryness in a gentle flow of nitrogen gas, then re-dissolved in $0.5 \mathrm{~mL}$ dimethyl sulfoxide (DMSO) and stored at $-20^{\circ} \mathrm{C}$ before bioassay. Six concentration levels of test solutions were obtained by 2 -fold dilution of each sediment raw extract and DMSO was used as solvent control for all assays.

\subsection{EROD assay}

Culture conditions of H4IIE rat hepatoma cells as well as the test conditions have been described previously by Donato et al. (1993) and Wang et al. (2003). Briefly, cells were cultured in Dulbecco's modified eagle medium DMEM (GIBCO Germany) supplemented with $10 \%$ (v/v) fetal bovine serum, 100 units/mL penicillin, and $100 \mu \mathrm{g} / \mathrm{mL}$ streptomycin. After incubated at $80 \%$ humidity and $5 \% \mathrm{CO}_{2}$ at $37^{\circ} \mathrm{C}$ for $24 \mathrm{~h}$, cells were exposed for $72 \mathrm{~h}$ to medium containing TCDD standards or DMSO or the test samples. Each test solution was assayed in triplicate, and three solvent controls and three blanks were assayed simultaneously on each 96-well plate. Then, EROD activity and protein content (Bradford, 1976) were measured using a Microplate Reader (TECAN-Genios, Austria). Data were normalized to total cellular protein. TCDD was used as a reference. The detection limit for the H4IIE assay was $18.5 \mathrm{fg}$ TCDD per well.

In general, to facilitate quantitative risk assessment and simplify data interpretation, the complex mixture's potency to cause dioxin-like activity and estrogenic activity were expressed relative to that of a well-characterized standard compound, namely, 2,3,7,8-tetrachlorodibenzo-p-dioxin (TCDD) and 17- $\beta$-estradiol (E2), respectively. In theory, expression of sample potency in terms of equivalents of a standard compound allows for comparison of diverse samples and may provide a basis for approximating risk to biological organisms with analogous biochemical processes (Villeneuve et al., 2000). In this study, levels of AhR agonists were obtained in comparison to the dose-response curve of the standard solution and expressed as TCDD equivalents $\left(\mathrm{TEQ}_{\mathrm{bio}}\right.$ ) in ng TCDD/kg dw.

\subsection{Recombinant yeast assay}

Recombinant yeast (Saccharomyces cerevisiae) cells were kindly provided by J.P. Sumpter from Brunel University, Uxbridge, UK. The yeast assay was performed mainly following the methods of Routledge and Sumpter (1996) and Wu et al. (2002).

The yeast strain was grown at $30^{\circ} \mathrm{C}, 130 \mathrm{rpm}$ overnight, using $\mathrm{CuSO}_{4}$ supplemented selective medium (SC medium). In performing the assay, exponentially growing overnight cultures were diluted with SC medium to an $\mathrm{OD}_{600 \mathrm{~nm}}$ of 0.25 . The assay media were seeded into 96-well plates at $200 \mu \mathrm{L}$ per well and incubated at $30^{\circ} \mathrm{C}$ with vigorous orbital shaking (130 rpm) on a titer plate shaker for $2 \mathrm{~h}$. All the samples were determined in a minimum of triplicate. Each plate contained a positive control (17 $\beta$-estradiol) and a negative control (DMSO). After measuring the cell density of the culture at $600 \mathrm{~nm}$ wavelength, $120 \mu \mathrm{L}$ of Z-buffer and $20 \mu \mathrm{L}$ chloroform were added and the enzyme reaction was started by adding $40 \mu \mathrm{L}$ o-nitrophenyl- $\beta$-D-galactopyranoside (ONPG). The expressed $\beta$-galactosidase activity in the tester strain was determined using ONPG as a substrate. The reactions were terminated by the addition of $100 \mu \mathrm{L} \mathrm{Na} \mathrm{CO}_{3}(1 \mathrm{M})$ and the $\mathrm{OD}_{420 \mathrm{~nm}}$ of the assay solutions was determined. Data were compared with E2 induction rates and expressed as estradiol equivalents $\left(\mathrm{EEQ}_{\mathrm{bio}}\right)$ in $\mathrm{ng} / \mathrm{kg} \mathrm{dw}$.

\subsection{Umu test}

The test strain (S. typhimurium TA1535/PSK1002) was kindly provided by Osaka Prefectural Institute of Public Health, Japan. The major advantages of this test are its sensitivity, rapidity, and ability to detect more mutagen classes using a single bacterial strain. Umu assays were carried out according to the procedure described previously by Oda (2004), with some modification. The overnight culture of the tester strain was diluted 50-fold with TGA medium and further incubated at $37^{\circ} \mathrm{C}$ for $2 \mathrm{~h}$. The resulting bacterial suspension was exposed for $2 \mathrm{~h}$ to sample material at different dilutions in the absence and presence of liver homogenate (S9 mixture for metabolic activation obtained from Chinese Center for Disease Control and Prevention) and then the bacterial density and the $\beta$-galactosidase activity were measured according to the modified method of Miller (1972) as described previously. The unit of $\beta$-galactosidase activity was calculated from the following equation:

units $=\frac{1000(\mathrm{OD} 420-1.75 \times \mathrm{OD} 550)}{t \times v \times \mathrm{OD} 600}$

where $t$ represents the reaction time ( $\mathrm{min}$ ) and $v$ the volume of cell culture used.

Induction ratios (IR) were measured in relation to a control without genotoxic compounds. A positive genotoxic response in the umu-C assay occurs when there is an induction ratio of at least two times the control. Moreover, the intensity of genotoxic effects of samples branded as positive result were also represented as sediment weight $(G)(\mathrm{mg})$ in one well of the 96 -well plates at IR 2.0 by linear interpolation.

\section{Results and discussion}

\subsection{AhR effect}

The crude extract of sediments from Meiliang Bay, Lake Taihu, induced significant AhR effects before the ecological remediation project. The bio-derived TEQ ranged from 17.8 to $38.5 \mathrm{ng}$ TCDD-EQ/kg dw. Koistinen et al. (1998) determined the dioxinlike activity of the sediments collected near a pulp mill and some sites in Lake Saimaa in Finland by measuring the induction of EROD activity in Hepa-1 mouse hepatoma cells. They found that all the samples contained greater concentrations of TCDD-EQs than the value $500 \mathrm{ng} / \mathrm{kg}$ dw. Bioassay-derived TEQs 


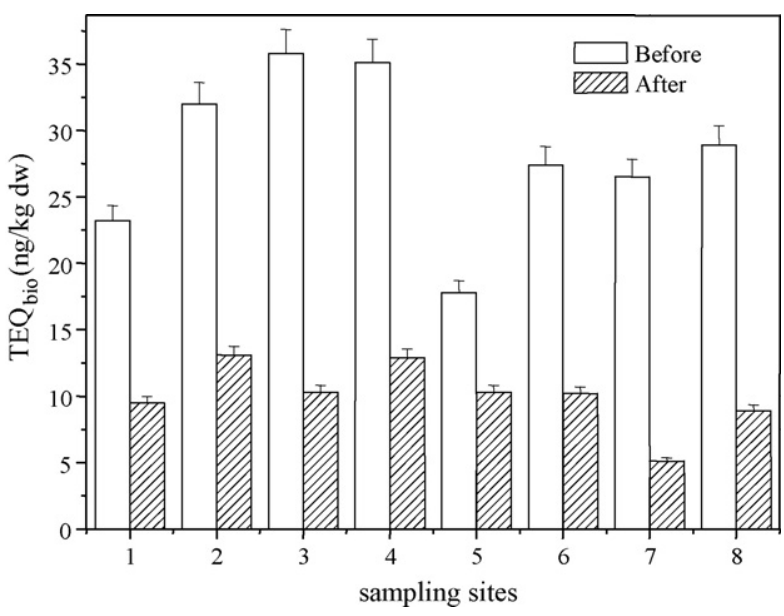

Fig. 2 - Comparison of the levels of AhR agonists before and after the ecological project.

in whole sediment extracts (prior to more extensive cleanup) from the Hudson-Raritan estuary and Newark Bay, New Jersey, USA, ranged from 170 to $93,000 \mathrm{ng} / \mathrm{kg}$ dw (Gale et al., 2000) based on EROD induction of H4IIE cells. Stronkhorst et al. (2002) investigated the presence of dioxin-like compounds in sediments from harbors along the Dutch coast using the dioxin receptor-chemically activated luciferase gene expression (DR-CALUX) bioassay and the DR-CALUX response ranged between 0.2 and $136 \mathrm{ng}$ TCDD-EQ/kg dw. So the level of dioxinlike chemicals in this bay is moderate compared with some other case studies.

The levels of AhR agonists decreased by $42.3-80.7 \%$ compared with the pre-remediation data (Fig. 2) after the ecological remediation project. The bio-derived TEQ ranged from 5.1 to $13.1 \mathrm{ng}$ TCDD-EQ/kg dw indicating that the dioxinlike chemicals were largely removed during restoration of the aquatic ecosystem. A similar study was reported by Engwall et al. (1998). They investigated the levels of dioxin-like contaminants before and after dredging of sediments of Lake Janernsjoen in Sweden, based on EROD induction in cultured chicken embryo livers and found that the dioxin-like activity in sediment after the dredging had only around $1 \%$ of the activity of the pre-dredging sediment.

\subsection{Estrogenic effect}

Estrogenic activity was measured in sediment extracts from all sediments before the project and the bioassay-derived estradiol equivalents (EEQs) ranged from 5.0 to $82.0 \mathrm{ng} / \mathrm{kg} \mathrm{dw}$. Oh et al. (2000) reported the levels of total estrogenic chemicals in sediment samples from Korea were between 3.39 and $10.70 \mathrm{ng} / \mathrm{kg}$ using MCF-7-BUS cells bioassay. Vondráček et al. (2001) tested estrogenic activity of crude sediment extracts using the induction of luciferase activity in the human breast carcinoma MCF-7 cells assay and found that the levels of estrogenic chemicals were between 4.75 and $22.61 \mathrm{ng} / \mathrm{kg}$ estradiol equivalents. Houtman et al. (2004) screened environmental samples for the presence of endocrine-disrupting compounds using estrogen-responsive chemical-activated luciferase gene expression (ER-CALUX) assays and showed that the endocrine-

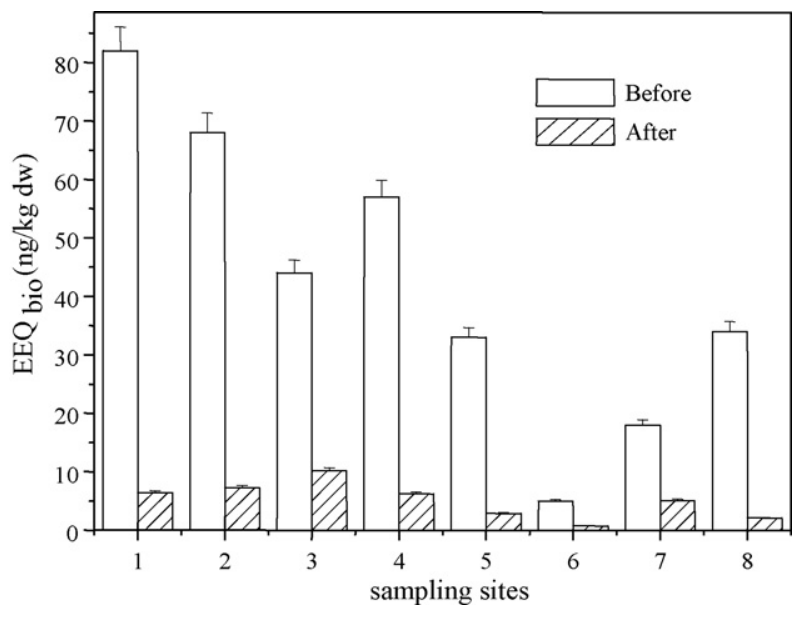

Fig. 3 - Comparison of the levels of estrogenic chemicals before and after the ecological project.

disrupting potencies in sediments from the Dutch delta ranged from $5.0 \pm 0.4$ to $340.0 \pm 6.9 \mathrm{ng} E E Q / \mathrm{kg}$ dw, with a median value of $64.8 \mathrm{ng} \mathrm{EEQ} / \mathrm{kg} \mathrm{dw}$.

After the project, the levels of estrogenic chemicals in the sediments decreased significantly by $71.3-93.6 \%$ (Fig. 3) which also showed that the remediation was successful in terms of removal of contaminated sediment. The levels of estrogenic chemicals ranged from 0.7 to $10.2 \mathrm{ng} \mathrm{EEQ} / \mathrm{kg}$ dw and were comparable to that in sediment from Ulsan Bay, Korea (Khim et al., 2001).

\subsection{Genotoxicity}

There are two different end-points, including induction ratios (IR) and the sediment weight $(G)$ at which the positive result could be used to evaluate the genotoxicity of soil or sediment samples (Whong et al., 1986; Xiao et al., 2006). Before the ecological project, no positive results could be observed when the bacterium was exposed to the sediment extracts without metabolic activation (-S9 mix). However, the genotoxic activities were greatly enhanced by the addition of $\mathrm{S9}$ mix (+S9 mix). The compounds in sediments that cause genotoxic effects could be indirect mutagens. In our earlier study, we demonstrated that the presence of PAHs, which is indirect acting mutagens, should be responsible for Ah-receptor effects in the sediments of the bay (Qiao et al., 2006).

Expressing the genotoxicity of sediments with respect to the sediment weight which leads to a 2-fold increase can be more scientifically justified. First, the IR is estimated as minimal concentrations of genotoxins required to produce a statistically significant increase from background controls according to the international agreement. Second, for the same IR, the less sediment weight required in the SOS/umu test, the greater the intensity of genotoxicity; again, on the circumstance of same sediment weight, different IR cannot reflect the relative genotoxicological potency of sediment samples since the mixture of numerous genotoxins leads to different curve slopes of dose-response relationship (Xiao et al., 2006). For the sediment samples taken before the project, values of $G$ were between 1.09 and $2.32 \mathrm{mg}$ sediment (dw) 


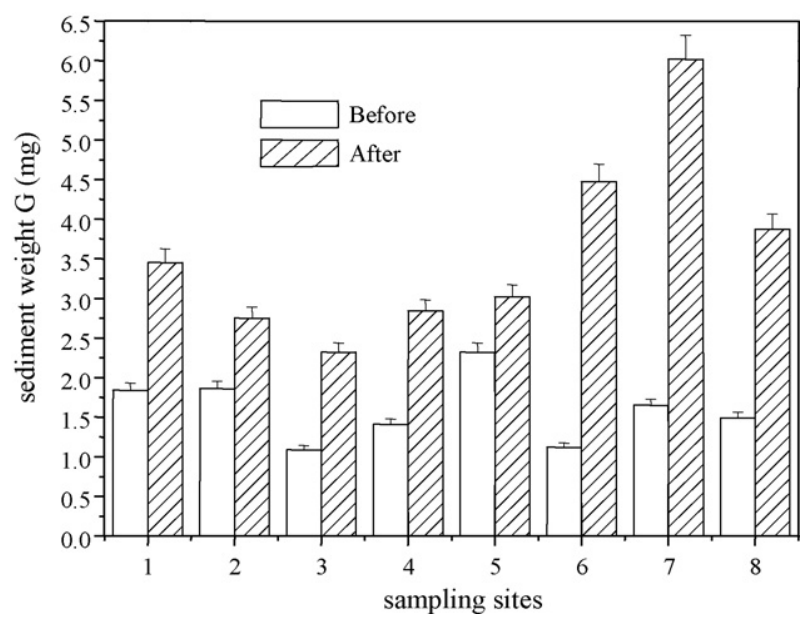

Fig. 4 - Comparison of the levels of genotoxic chemicals before and after the ecological project.

per well with a mean value of $1.60 \mathrm{mg}$ sediment (dw) per well.

After the ecological project, the umu test showed that the sediment weight $(G)$ that caused positive results of IR 2 ranged from 2.32 to $6.02 \mathrm{mg}$ per well (Fig. 4). Increasing $G$ value indicates decreasing genotoxicity. Mendonça and Picado (2002) evaluated the landfarming treatment technique that conducted in contaminated soils by ecotoxicological tests. The potential genotoxicity of the samples was determined using Mutatox $^{\circledR}$ test with and without metabolic activation, and after 2 months of treatment no genotoxic effects were registered. Rila and Eisentraeger (2003) assessed genotoxicity of soil samples using multiple methods including the umu test. They showed that the remediated sample should still be considered as genotoxic though hazardous compounds were not detected by chemical analysis. Thus it can be concluded that assessment and remediation of contaminated sites without consideration of bioassay is not sufficient.

The decreasing toxicity in this study is probably due to the dredging of sediments as well as the uptake of planted floating-leaf and floating macrophytes. Lake Taihu is a shallow lake and the onshore wind flow with long fetch can result in high waves and sediment resuspension. As a consequence, it is more easily for the plant to uptake.

\section{Conclusion}

In the present study, the selected bioassays, including EROD assay, recombinant yeast assay and umu test, were used for testing different toxic potencies in sediment extracts from Meiliang Bay, Lake Taihu, both before and after the ecological project. Results showed that the ecological project has effectively removed the toxic effect of sediments, especially the estrogenic chemicals. It suggested that in vitro bioassay based on various specific modes of action can predict the toxicity change of complex ecosystem during the remediation project without performing expensive chemical analysis. Some chemicals were then selected to be analyzed based on the acquired specific toxicity information. By integrating bioassay results and the selected chemical analysis, one can identify the possible risk stressors that contribute most to the adverse effects in the concerned area.

\section{Acknowledgements}

The authors acknowledge the support of Chinese Academy of Science (KZCX1-YW-14-6) and National Natural Science Foundation of China (40590390 and 20507019) for conducting this research.

\section{REFERENCES}

Anderson, B.S., Hunt, J.W., Philips, B.M., Stoelting, M., Becker, J., Fairey, R., Puckett, H.M., Stephenson, M., Tjeerdema, R.S., Martin, M., 2000. Ecotoxicologic change at a remediated superfund site in San Francisco, California, USA. Environ. Toxicol. Chem. 19, 879-887.

Bradford, M.M., 1976. A rapid and sensitive method for the quantification of microgram quantities of protein utilizing the principle of protein dye binding. Anal. Biochem. 72, 248-254.

Carone, M.T., Greco, M., Molino, B., 2006. A sediment-filter ecosystem for reservoir rehabilitation. Ecol. Eng. 26, 182-189.

Denison, M.S., Zhao, B., Baston, D.S., Clark, G.C., Murata, H., Han, D., 2004. Recombinant cell bioassay systems for the detection and relative quantitation of halogenated dioxins and related chemicals. Talanta 63, 1123-1133.

Donato, M.T., Gómez-Lechón, M.J., Castell, J.V., 1993. A microassay for measuring cytochrome P450IA1 and P450IIB1 activities in intact human and rat hepatocytes cultured on 96-well plates. Anal. Biochem. 213, 29-33.

Engwall, M., Naef, C., Broman, D., Brunstroem, B., 1998. Biological and chemical determination of contaminant levels in settling particulate matter and sediments. A Swedish river system before, during, and after dredging of PCB-contaminated lake sediments. AMBIO 27, 403-410.

Gale, R.W., Long, E.R., Schwartz, T.R., Tillitt, D.E., 2000. Evaluation of planar halogenated and polycyclic aromatic hydrocarbons in estuarine sediments using ethoxyresorufin-o-deethylase induction of H4IIE cells. Environ. Toxicol. Chem. 19, 1348-1359.

Giesy, J.P., Hilscherova, K., Jones, P.D., Kannan, K., Machala, M., 2002. Cell bioassays for detection of aryl hydrocarbon (AhR) and estrogen receptor (ER) mediated activity in environmental samples. Mar. Pollut. Bull. 45, 3-16.

Hamblen, E.L., Cronin, M.T.D., Schultz, T.W., 2003. Estrogenicity and acute toxicity of selected anilines using a recombinant yeast assay. Chemosphere 52, 1173-1181.

Houtman, C.J., Cenijn, P.H., Hamers, T., Lamoree, M.H., Legler, J., Murk, A.J., Brouwer, A., 2004. Toxicological profiling of sediments using in vitro bioassays, with emphasis on endocrine disruption. Environ. Toxicol. Chem. 23, 32-40.

Jiang, J.G., Shen, Y.F., 2006. Estimation of the natural purification rate of a eutrophic lake after pollutant removal. Ecol. Eng. 28, 166-173.

Khim, J.S., Villeneuve, D.L., Kannan, K., Koh, C.H., Giesy, J.P., 1999. Characterization and distribution of trace organic contaminants in sediment from Masan Bay, Korea. 2. In vitro gene expression assays. Environ. Sci. Technol. 33, 4206-4211.

Khim, J.S., Lee, K.T., Villeneuve, D.L., Kannan, K., Giesy, J.P., Koh, C.H., 2001. In vitro bioassay determination of dioxin-like and estrogenic activity in sediment and water from Ulsan Bay and its vicinity, Korea. Arch. Environ. Contam. Toxicol. 40, 151-160.

Koistinen, J., Soimasuo, M., Tukia, K., Oikari, A., Blankenship, A., Giesy, J.P., 1998. Induction of EROD activity in Hepa-1 mouse hepatoma cells and estrogenicity in MCF-7 human breast 
cancer cells by extracts of pulp mill effluents, sludge, and sediment exposed to effluents. Environ. Toxicol. Chem. 17, 1499-1507.

Kubota, A., Iwata, H., Tanabe, S., Yoneda, K., Tobata, S., 2004. Levels and toxicokinetic behaviors of PCDD, PCDF, and coplanar PCB congeners in common cormorants from Lake Biwa, Japan. Environ. Sci. Technol. 38, 3853-3859.

Legler, J., Dennekamp, M., Vethaak, A.D., Brouwer, A., Koeman, J.H., Burg, B., Murk, A.J., 2002. Detection of estrogenic activity in sediment-associated compounds using in vitro reporter gene assays. Sci. Total Environ. 293, 69-83.

Ma, M., Wang, C.X., Wang, Z.J., 2005. Assessing toxicities of hydrophobic organic pollutants in Huaihe River by using two types of sampling. J. Environ. Sci. Health A 40, 331-342.

Masunaga, S., Yao, Y., Ogura, I., Nakai, S., Kanai, Y., Yamamuro, M., Nakanishi, J., 2001. Identifying sources and mass balance of dioxin pollution in Lake Shinji Basin, Japan. Environ. Sci. Technol. 35, 1967-1973.

Mendonça, E., Picado, A., 2002. Ecotoxicological monitoring of remediation in a coke oven soil. Environ. Toxicol. 17, 74-79.

Miller, J.H., 1972. Experiments in Molecular Genetics. Cold Spring Harbor Laboratory. Cold Spring Harbor, New York, pp. 352-355.

Miller, K.A., Addison, R.F., Bandiera, S.M., 2003. Hepatic CYP1A levels and EROD activity in English sole: biomonitoring of marine contaminants in Vancouver Harbour. Mar. Environ. Res. 57, 37-54.

Motohashi, N., Saito, Y., 2002. Induction of SOS response in Salmonella typhimurium TA4107/pSK1002 by peroxynitrite-generating agent, $\mathrm{N}$-morpholino sydnonimine. Mutat. Res. 502, 11-18.

Murphy, T., 2000. Coal tar in Hamilton Harbour-attempts at biological restoration guidelines. Environ. Toxicol. 15, 484-495.

Oda, Y., Nakamura, S., Oki, I., Kato, T., Shinagawa, H., 1985. Evaluation of the new system (umu-test) for the detection of environmental mutagens and carcinogens. Mutat. Res. 147, 219-229.

Oda, Y., 2004. Analysis of the involvement of human $\mathrm{N}$-acetyltransferase 1 in the genotoxic activation of bladder carcinogenic arylamines using a SOS/umu assay system. Mutat. Res. 554, 399-406.

Oh, S.M., Choung, S.Y., Sheen, Y.Y., Chung, K.H., 2000. Quantitative assessment of estrogenic activity in the water environment of Korea by the E-SCREEN assay. Sci. Total Environ. 263, 161-169.

Qiao, M., Wang, C.X., Huang, S.B., Wang, D.H., Wang, Z.J., 2006. Composition, sources and potential toxicological significance of PAHs in the surface sediments of the Meiliang Bay, Taihu Lake. China Environ. Int. 32, 28-33.

Qin, B.Q., Hu, W.P., Liu, Z.W., Xie, P., Yin, C.Q., Gao, G., Gu, X.H., $\mathrm{Xu}, \mathrm{Z} . \mathrm{K} .$, 2007. Ecological engineering experiment on water purification in drinking water source in Meiliang Bay, Lake Taihu. Acta Sci. Circum. 27 (1), 5-12 (in Chinese).
Rila, J.P., Eisentraeger, A., 2003. Application of bioassays for risk characterisation and remediation control of soils polluted with nitroaromatics and PAHs. Water Air Soil Pollut. 148, 223-242.

Routledge, E.J., Sumpter, J.P., 1996. Estrogenic activity of surfactants and some of their degradation products assessed using a recombinant yeast screen. Environ. Toxicol. Chem. 15, 241-248.

Schulz, R., Peall, S.K.C., Hugo, C., Krause, V., 2001. Concentration, load and toxicity of spraydrift-borne azinphos-methyl at the inlet and outlet of a constructed wetland. Ecol. Eng. 18, 239-245.

Simon, M.A., Bonner, J.S., Page, C.A., Townsend, R.T., Mueller, D.C., Fuller, C.B., Autenrieth, R.L., 2004. Evaluation of two commercial bioaugmentation products for enhanced removal of petroleum from a wetland. Ecol. Eng. 22, 263-277.

Stegeman, J.J., Schlezinger, J.J., Craddock, J.E., Tillitt, D.E., 2001 Cytochrome $\mathrm{P} 450$ 1A expression in midwater fishes: potential effects of chemical contaminants in remote oceanic zones. Environ. Sci. Technol. 35, 54-62.

Stronkhorst, J., Leonards, P., Murk, A.J., 2002. Using the dioxin receptor-CALUX in vitro bioassay to screen marine harbor sediments for compounds with a dioxin-like mode of action. Environ. Toxicol. Chem. 21, 2552-2561.

Villeneuve, D.L., Blankenship, A.L., Giesy, J.P., 2000. Derivation and application of relative potency estimates based on in vitro bioassay results. Environ. Toxicol. Chem. 19, 28352843.

Vondráček, J., Machala, M., Minksová, K., Bláha, L., Murk, A.J., Kozubík, A., Hofmanová, J., Hilscherová, K., Ulrich, R., Ciganek, M., Neča, J., Švrčková, D., Holoubek, I., 2001. Monitoring river sediments contaminated predominantly with polyaromatic hydrocarbons by chemical and in vitro bioassay techniques. Environ. Toxicol. Chem. 20, 1499-1506.

Wang, C.X., Wang, Y., Kiefer, F., Yediler, A., Wang, Z.J., Kettrup, A., 2003. Ecotoxicological and chemical characterization of selected treatment process effluents of municipal sewage treatment plant. Ecotoxicol. Environ. Saf. 56, 211-217.

Whong, W.Z., Wen, Y.F., Stewart, J., Ong, T.M., 1986. Validation of the SOS/Umu test with mutagenic complex mixtures. Mutat. Res. 175, 139-144.

Wu, W.Z., Wang, J.X., Zhao, G.F., You, L., 2002. The emission soot of biomass fuels combustion as a source of endocrine disrupters. J. Environ. Sci. Health A 37, 579-600.

Wu, J.Y., Shen, L., Gao, G., Lin, G.F., Ke, X., Shen, J.H., 2004. Environ. Monit. Assess 98, 225-234.

Xiao, R.Y., Wang, Z.J., Wang, C.X., Yu, G., 2006. Soil screening for identifying ecological risk stressors using a battery of in vitro cell bioassays. Chemosphere 64, 71-78.

Zuo, Q., Lu, C.A., Zhang, W.L., 2003. Preliminary study of phosphorus runoff and drainage from a paddy field in the Taihu Basin. Chemosphere 50, 689-694. 